\title{
Research on the Transformation and Development of Traditional Media in the New Media Era
}

\author{
Xianzhe Wang \\ College of Arts, Beihua University, Jilin, China \\ Email: XianzheWang@163.com
}

How to cite this paper: Wang, X. Z. (2021). Research on the Transformation and Development of Traditional Media in the New Media Era. Open Journal of Social Sciences, 9, 457-462.

https://doi.org/10.4236/jss.2021.93029

Received: February 26, 2021

Accepted: March 27, 2021

Published: March 30, 2021

Copyright $\odot 2021$ by author(s) and Scientific Research Publishing Inc. This work is licensed under the Creative Commons Attribution International License (CC BY 4.0).

http://creativecommons.org/licenses/by/4.0/

\section{(c) (i) Open Access}

\begin{abstract}
To seek transformation and development is a necessary measure and beneficial exploration for traditional media to adapt to market competition, industry trend and implement self innovation under the new media era background. In the new media era, traditional media can optimize the allocation of traditional media resources, change the information dissemination mode of traditional media, and gather the public opinion guidance ability of traditional media through transformation and development, so as to reshape competitiveness, expand influence, and strengthen appeal. Based on the background of the new media era, combined with the operating characteristics of traditional media, traditional media should change the concept and innovate the system in parallel, take account of content innovation and form iteration and pay equal attention to talent cultivation and science and technology empowerment, and form a development situation of system foundation, innovation empowerment and talent assistance, in order to realize the efficient landing of transformation and realize its own efficient, steady and sustainable development.
\end{abstract}

\section{Keywords}

New Media, Traditional Media, Transformation and Development

\section{Introduction}

With the rapid development and wide popularization of Internet technology, new media forms based on digital technology, wireless communication, satellite communication and other technical means appear rapidly and develop widely (Cao, 2017). The representative new media includes Internet social platform, we-media platform and so on. With the advantages of Internet technology, such as high openness, wide coverage and high efficiency, new media occupy more 
and more discourse power gradually, influence and guiding force in the field of information communication, thus the field of information communication enters the era of new media (Jin, 2018).

In the era of new media, on the one hand, new media efficiently screens, analyzes, mines and predicts massive information to improve the innovation and accuracy of content. On the other hand, it makes use of words, pictures, audio, video and other forms to visually and audibly process the content to realize the interesting and efficient form of communication. In the process of superimposed information communication, new media interacts with the audience, which leads to the growth of the influence of new media. In this context, the traditional media should face up to their own shortcomings and learn from the advantages of new media elements to achieve their own transformation and development (Liang et al., 2016).

\section{The Value Analysis of the Transformation and Development of Traditional Media in the New Media Era}

Analyzing the value of the transformation and development of traditional media in the new media era is helpful to clarify the direction and goal of the transformation of traditional media, and to explore the practical path of the transformation of traditional media. The report analyzes from the three dimensions of resource allocation, information dissemination mode and public opinion guidance ability, and explores that traditional media can reshape competitiveness, expand influence and strengthen appeal through transformation, which is the value connotation of traditional media transformation and development in the new media era (Nan, 2020).

\subsection{Optimize the Allocation of Traditional Media Resources, Reshape the Competitiveness of Traditional Media}

Optimizing the allocation of traditional media resources and reshaping the competitiveness of traditional media are the primary value of the transformation and development of traditional media in the new media era. From the perspective of practical operation, traditional media can optimize its own resource elements through transformation (Neng, 2018). First, transformation and development can accelerate the optimization of the talent structure of traditional media, highlight the cultivation of young teams with new technology, new ideas, new vision, new goals and new abilities, so as to provide effective support for the sustainable development of traditional media. Second, through transformation and development, traditional media can build new traffic channels to connect customers, superimpose its own offline advantages, and traditional media can realize its own online and offline synchronous collaborative development, and finally fully reflect its own content advantages. Third, based on the transformation and development, traditional media can integrate its own media technology resources, highlight the research and application of media technology, and truly enhance resource ability and technology ability of traditional media, and ultimately improve 
their core competitiveness ( $\mathrm{Wu}, 2018)$.

\subsection{Change the Traditional Media Information Dissemination Mode, Expand the Influence of Traditional Media}

It is the core value of the transformation and development of traditional media in the new media era to change the information transmission mode of traditional media and expand the influence of traditional media. There is no doubt that the Internet has had a great impact on the way of human production and life, even in the field of information dissemination. In the era of new media, the information transmission mode of traditional media is too rigid. It is not only lack of enough attractive information in content, but also slightly dull and boring in form. It is difficult to attract young customers in the new era and meet the needs of the market. At the same time, the direction of information dissemination of traditional media is usually one-way and lack of communication and interaction between the information transmitter and the audience. Thus reducing the influence and attraction of traditional media itself. Through the transformation and development, the traditional media will be benchmarked with the functions, contents and modes of new media, learn from their excellent experience and modes, innovate their own information dissemination mode, and expand their influence (Yuan, 2016).

\subsection{Focus on the Ability of Traditional Media to Guide Public Opinion and Strengthen the Appeal of Traditional Media}

The main value of the transformation and development of traditional media in the new media era is to focus on the public opinion guidance ability of traditional media and strengthen the appeal of traditional media. In recent years, with the rapid development of internet platform and new media represented by internet social platform and we-media, the influence of information dissemination has far exceeded that of traditional media, and the appeal of new media to public opinion has been continuously enhanced. However, due to the scattered resources, the innovation ability, technical ability, channel ability and operation ability of traditional media are generally insufficient, which leads to the decline of traditional media. The sharp decline of communication power and influence is tantamount to the loss of the main position of traditional media. In this case, through the transformation and development, the traditional media can force its own reform to be prominent, integrate its own resources, go to battle light, improve the attractiveness, innovation and scientificity of its products, better meet the objective needs of the market so as to strengthen its appeal.

\section{Research on the Transformation and Development Path of Traditional Media in the New Media Era}

Based on the analysis of the direction and goal of the transformation and development of traditional media, combined with the actual situation of traditional media management, this part explores the implementation path of the transfor- 
mation and development of traditional media in the new media era specifically from six aspects, which are changing the concept, innovating the system, innovating the content, iterating the form, cultivating talents and enabling science and technology. The specific analysis is as follows.

\subsection{Change Ideas and Reform System to Ensure the Efficient Reform of Traditional Media in the New Media Era}

It is the basic path for the transformation and development of traditional media in the new media era to change the concept and reform the system, and the main goal is to ensure the efficient reform of traditional media in the new media era. On the one hand, the traditional media must change the concept of information dissemination. And fully realize that the audience is the core of information dissemination and has irreplaceable subjectivity. In the transformation and development strategy, not only the managers should reach a high degree of consensus in the management, but also strengthen the education and guidance of the transformation and development consensus for the grass-roots staff. In order to ensure the smooth reform of traditional media in the new media era, the managers should not only implement the advanced new media operation concept, but also obtain the broad consensus of employees. On the other hand, it is necessary to further clarify the specific operation system in the field of information dissemination and establish a scientific, comprehensive and executable operation system, which includes not only the design of the functional coordination of each post, but also the incentive and restraint mechanism for each post and personnel. Media organisations should constantly release the internal management dividend through institutional reform, highlight the institutional advantages, resource advantages and organizational advantages in the process of competition between traditional media and new media, and ensure the efficient reform of traditional media in the new media era (Zeng \& Wei, 2016).

\subsection{Content Innovation and Form Iteration, Reconstruct the Traditional Media Operation System in the New Media Era}

Both content innovation and form iteration are the key path for the transformation and development of traditional media in the new media era. The main goal is to reconstruct the traditional media operation system in the new media era. From the past history, traditional media generally attach importance to content innovation, and want to attract the majority of Internet customers with the innovation of content. However, from the perspective of practice, due to the lack of flexible market mechanism and competitiveness in the operation mode of traditional media and the lack of high-quality talents, the content innovation of traditional media is not only lack of foundation, but also difficult to achieve the effective touch of innovative content to customers, and thus difficult to really play its effectiveness. On the contrary, due to the lack of innovation in content, the content of traditional media lags behind and lacks attraction to customers. At the same time, because of the aging structure of the talent team, low know- 
ledge skills and comprehensive literacy, it is unable to iterate and innovate the content form of information dissemination, thus reducing the operation efficiency of traditional media in the new media era. Therefore, the new media platform must strengthen the innovation in the content of information dissemination, and at the same time, it should take into account the update iteration of various forms of information dissemination in the field of information dissemination, keep up with the rhythm, and really bring a good sense of experience to customers.

\subsection{Pay Equal Attention to Talent Cultivation and Technology Empowerment, and Highlight the Operation Guarantee of Traditional Media in the New Media Era}

Paying equal attention to talent cultivation and technology empowerment is the supporting path for the transformation and development of traditional media in the new media era. The main goal is to ensure the operation guarantee of traditional media in the new media era. In the era of knowledge economy, talents and science and technology are the core competitiveness. Therefore, in order to transform and develop successfully in the new media era, the traditional media must recruit excellent talents, increase their own technology investment, and realize the high-efficiency empowerment of science and technology, so as to provide substantial guarantee in the level of human resources and science and technology. This will greatly activate the operation vitality of traditional media, and truly provide a favorable operation guarantee for the transformation and development of traditional media.

\section{Research Conclusion}

In a word, transformation and development is the only way for traditional media in the new media era, and is the inevitable choice to achieve its own efficient, stable and sustainable development. Under the impact of new media, traditional media should integrate its own elements, examine its own shortcomings, learn from the development experience of new media, comprehensively realize its own ideological transformation, institutional transformation and mode transformation, and truly improve the competitiveness of traditional media in market operation, its influence in information dissemination and its appeal in information transmission.

\section{Conflicts of Interest}

The author declares no conflicts of interest regarding the publication of this paper.

\section{References}

Cao, J. D. (2017). Analysis on the Transformation and Development Path of Traditional Newspaper Industry in the Era of Financial Media. Publishing Wide Angle, 9, 22-24.

Jin, Y. Q. (2018). Transformation and Development of Traditional Media Hosts in the All 
Media Era. Journal of Chizhou University, 32, 117-119.

Liang, M. P., Pan, M. Z., Huang, Z. H., Ling, Q., Huang, Y. Y., \& Li, C. L. (2016). Discussion on the Transformation and Development of Traditional Journals in the New $\mathrm{Me}$ dia Era. Communication and Copyright, 6, 31-32 + 35 .

Nan, W. D. (2020). Research on the Transformation and Development Path of Traditional Media in the Era of Financial Media. Media Forum, 3, 28-29.

Neng, D. (2018). Research on the Transformation and Development of Local Mainstream Traditional Media in the Era of Wisdom and Intelligent Media-Taking Hubei Radio and Television Group's “Two Sessions” Report as an Example. TV Research, 5, 58-60.

$\mathrm{Wu}$, N. L. (2018). Research on the Transformation and Development of Traditional TV in the New Media Era. Communication Power Research, 2, 69.

Yuan, J. (2016). Research on the Transformation and Development of Traditional TV in the New Media Era. Changsha: Hunan Normal University.

Zeng, R. X., \& Wei, F. (2016). Transformation and Development Path of Traditional Media in New Media Era-Taking Hubei Daily Media Group as an Example. Media, 2, 34-37. 